\title{
The slab gel electrophoretic assay for detection and investigation of chrysanthemum chlorotic mottle viroid (CChMV) in infected plants
}

\author{
Guy MACQUAIRE, Marie MONSION, Jean-Claude BACHELIER, Christine FAYDI et Jean DUNEZ
}

Station de Pathologie végétale, I.N.R.A. Bordeaux, 33140 Pont-de-la-Maye

\author{
ABSTRACT \\ Viroids, \\ Detection, \\ Polyacrylamide gel elec- \\ trophoresis, \\ Chrysanthemum chloro- \\ tic mottle viroid, \\ P.A.G.E.
}

\begin{abstract}
For a long time viroids have been detected by bioassay. Electrophoretic assay was introduced in 1976 for Potato spindle tuber. In the past months we developed this technique for Chrysanthemum stunt. Till now, the second Chrysanthemum viroid, Chrysanthemum chlorotic mottle was still detected by bioassay. Even under the best environmental conditions and especially high temperature and illumination the test is long (4-8 weeks) and not reliable. We demonstrate here that the electrophoretic assay is also very suitable for the detection of CChMV. When carried with slab gels stained with ethidium bromide it exhibits a high sensitivity and presents the same advantages, reliability and versatility, as observed with PSTV and CSV.
\end{abstract}

\section{RÉSUMÉ}

Viroïdes, Indexage, Electrophorèse en gel de polyacrylamide, Viroïde de la Marbrure chlorotique au Chrysanthème.

\begin{abstract}
L'électrophorèse sur gel de polyacrylamide en plaques, une technique d'indexage du viroïde des marbrures chlorotiques du Chrysanthème

Le Chrysanthème peut être infecté par deux viroïdes, le rabougrissement (CSV) et les marbrures chlorotiques (CChMV). L'indexage classique consiste en une transmission par greffe sur des variétés indicatrices sensibles : les variétés utilisées sont le plus généralement « Mistletoe » d'une part, « Deep Ridge » ou «Yellow Delaware " d'autre part, pour le rabougrissement et les marbrures chlorotiques respectivement. Dans les meilleures conditions d'environnement $\left(28-30^{\circ} \mathrm{C}, 15000\right.$ lux et 85 p. 100 d'humidité), les symptômes caractéristiques n'apparaissent que plusieurs semaines après inoculation et le pourcentage des plantes inoculées développant des symptômes est faible notamment dans le cas du CChMV. Dans les dernières années, une technique d'électrophorèse a été développée d'abord pour l'indexage du viroïde des tubercules fusiformes de la Pomme de terre (PSTV), puis pour celui du rabougrissement du Chrysanthème. La technique utilisée pour le CSV a été appliquée au CChMV : elle est fondée sur l'extraction des acides nucléiques de la plante, l'élimination des gros RNA par $\mathrm{LiCl} 2 \mathrm{M}$ et la séparation des petits RNA par électrophorèse sur un gel de polyacrylamide à $5 \mathrm{p} .100$ en plaque. La coloration des acides nucléiques par le bromure d'éthidium confère une grande sensibilité à cette technique qui peut détecter moins de $10 \mathrm{ng}$ de RNA viroïdal. Ainsi le CChMV a pu être mis en évidence dans des échantillons végétaux très réduits : il suffit en effet d'un échantillon de $12 \mathrm{mg}$ de jeunes feuilles ou de racines pour détecter le viroïde qui peut être également observé dans des échantillons de $100 \mathrm{mg}$ de feuilles âgées ou de tiges. La technique électrophorétique d'indexage est également applicable à des jeunes plantes issues de cultures in vitro. Par ailleurs, l'indexage électrophorétique est plus faible que l'indexage biologique; en effet, le virö̈de est régulièrement mis en évidence dans des plantes inoculées par CChMV et ne présentant pas de symptômes. Les deux virö̈des, CSV et CChMV, qui ont en gel de polyacrylamide à 5 p. 100 la même mobilité, ne peuvent être différenciés par la technique électrophorétique qui, en contre-partie, présente l'avantage de pouvoir, dans les mêmes conditions, déceler dans un contrôle de routine aussi bien le CSV que le CChMV.
\end{abstract}

\section{INTRODUCTION}

Chrysanthemum chlorotic mottle disease was firstly observed in 1967 in the United States and reported by DIMOCK \& GEISSENGER in 1969. In 1975, ROMAINE \& HORST described the causal agent as a viroid. Until now the only european country where the disease has been noticed is Denmark (PALUDAN, 1974). Chrysanthemum cultures can be infected with two viroids, stunt (CSV) and chlorotic mottle (CChMV) viroids. The first viroid is considered as a very severe pathogen inducing several types of disorders on many susceptible cultivars. On the contrary, CChMV is associated with rather mild symptoms and most cultivars are symptomless when infected. The only symptoms developed by the most susceptible cultivars are leaf mottle, slight reduction of the leaf and flower size and occasionally a mild stunting of the whole plant. 
The usual detection of CChMV is by indexing on susceptible cultivars. The most frequently used are "Deep Ridge" and Yellow Delaware : they exhibit leaf mottle and yellowing which can extend to the whole plant. These symptoms appear 3 weeks after inoculation and can be particularly intense when the plants are grown at a temperature of $28-30^{\circ} \mathrm{C}$ and 15000 lux illumination. This type of bioassay has several disadvantages. It is rather long and expensive because of the space required in growth chambers. Moreover, as the rate of CChMV transmission is often low and symptom development erratic, this technique is not reliable.

We tried to adapt the electrophoretic assay developed by MORRIS \& WRIGHT (1975) and modified by SCHUMANN et al. (1978) for PSTV. Recently, we have briefly reported (MONSION et al., 1980) the possibility of applying slab gel electrophoresis to the detection of both CSV and CChMV.

This paper deals more specifically with CChMV and presents more details on the extraction conditions of the viroid. The results presented here give some indications on the distribution of the viroid in the infected plant, the sensitivity and the reliability of this test as an indexing technique compared to the bioassay. We stress the applications of the slab gel electrophoretic assay as a quantitative method very useful during the purification of the viroid RNA.

\section{MATERIAL AND METHODS}

\section{Material}

The CChMV strain used in our work was obtained from PALUDAN. It was propagated in the greenhouse at $22-25^{\circ} \mathrm{C}$ or in a growth chamber (humidity 85 p. 100 , illumination 15000 lux (fluorescent lamps) for $16 \mathrm{~h}$, temperature $30^{\circ} \mathrm{C}$ during the light period and $28^{\circ} \mathrm{C}$ during the dark period).

Cultivars used for propagating CChMV were "Deep Ridge", "Yellow Delaware" and "Bonnie Jean". This last cultivar was demonstrated in 1976 (BACHELIER et al.) to be also very susceptible to CSV.

The apparatus used for electrophoresis was that of Pharmacia (GE 4). It can hold 4 slabs $(8 \times 8 \times 0.27 \mathrm{~cm})$ of 6 tracks each.

Stained gels were photographed with a Polaroid type 665 under short wave UV.

\section{Methods}

\section{Nucleic acid extraction}

RNAs are extracted according to MORRIS \& SMITH (1977) as slightly modified by MONSION et al. (1980). Two buffers were used and compared. The glycine buffer $(0.2 \mathrm{M}$, pH 9.5) is commonly used for PSTV and CSV; borate buffer $(0.2 \mathrm{M}, \mathrm{pH} 9)$, described by ROMAINE \& HORST (1975) as particularly suitable for CChMV extraction and transmission, was also employed in our trials.

Samples of 0.250 to $1 \mathrm{~g}$ plant material are blended using a mortar or a Potter homogenizer in 1 vol. buffer $(w: v=1)$ supplemented with sodium diethyldithiocarbamate $(0.004 \mathrm{M})$ and 2 vol. $(\mathrm{w}: \mathrm{v}=2$ ) phenol-chloroform-pentanol (v: v : v = 25:24:1).

After low speed centrifugation the aqueous phase was added with $1 \mathrm{M}$ or $2 \mathrm{M} \mathrm{LiCl}$. After $2 \mathrm{~h}$ precipitation at $4{ }^{\circ} \mathrm{C}$ and low speed centrifugation the supernatant was collected and the pellet resuspended in the buffer. Both fractions were dialyzed overnight against sterile water; nucleic acids were precipitated by ethanol in the presence of $0.2 \mathrm{M}$ potassium acetate. In some cases the $\mathrm{LiCl}$ treatment was omitted: the aqueous phase was dialyzed and the nucleic acids precipitated by ethanol overnight at $-20{ }^{\circ} \mathrm{C}$.

After ethanol precipitation, the suspension was centrifugated for $20 \mathrm{~min}$ at $15000 \mathrm{rpm}$ in a Beckman rotor JA 17 ; the pellet was dissolved in $100 \mu$ l sterile distilled water and the resulting solution supplemented with $10 \mathrm{p} .100$ RNase free sucrose.

\section{Electrophoretic procedure}

Electrophoresis was carried out on 5 p. 100 acrylamide slab gels. Samples of $25 \mu$ RNA solution were applied onto each track. The electrolyte consisted of $0.04 \mathrm{M}$ Tris, $0.02 \mathrm{M}$ Sodium acetate, $0.001 \mathrm{M} \mathrm{Na} 2$ EDTA, pH 7.8. Bromophenol blue was used as a migration marker. Gels were pre-electrophoresed for $1 \mathrm{~h}$ at 120 volts and $200 \mathrm{~mA}$.

After sample application, gels were electrophoresed for $20 \mathrm{~min}$ at 70 volts, then $1 \mathrm{~h}$ at 125 volts and $280 \mathrm{~mA}$. Electrophoresis was carried out at $12^{\circ} \mathrm{C}$.

After electrophoresis, the slabs were washed in distilled water, stained for $1 \mathrm{~h}$ in ethidium bromide solution $(8 \mathrm{mg} / \mathrm{l}$ water). Excess of stain was eliminated by rinsing the slabs for a few minutes in distilled water.

\section{RESULTS}

\section{Extraction of viroid RNA}

Two buffers were used for RNA extraction, borate and glycine. The results (table 1 and fig. 1) are based on the minimum amount of infected material necessary for detecting viroid RNA in the different fractions. CChMV did not behave differently from the other viroids: it did not precipitate in the presence of $\mathrm{LiCl}$ and no significant

TABLE

Effect of extraction buffer and LiCl treatment on the detection of CChMV : (Results are expressed in the minimum amount of infected plant material required to detect the viroid $R N A$ )

Effet du tampon d'extraction et du traitement LiCl sur la détection du CChMV (les résultats sont exprimés en quantité minimale de matériel végétal infecté nécessaire pour détecter le RNA viroïdal

\begin{tabular}{lccccc}
\hline \hline $\begin{array}{c}\text { Extraction } \\
\text { buffer }\end{array}$ & $\begin{array}{c}\text { No LiCl } \\
\text { treatment }\end{array}$ & $1 \mathrm{M} \mathrm{LiCl}$ & $2 \mathrm{M} \mathrm{LiCl}$ \\
& & $\mathrm{S}\left(^{*}\right)$ & $\mathrm{P}\left({ }^{*}\right)$ & $\mathrm{S}$ & $\mathrm{P}$ \\
\hline $\begin{array}{l}\text { Glycine } \\
\text { Borate }\end{array}$ & $100 \mathrm{mg}$ & $100 \mathrm{mg}$ & $-\left(^{1}\right)$ & $12 \mathrm{mg}$ & - \\
\hline
\end{tabular}

(*) $\mathrm{S}$ : supernatant from $\mathrm{LiCl}$ treatment ; $\mathrm{P}$ : pellet from $\mathrm{LiCl}$ treatment.

(1) - : no viroid RNA was detected : maximum amount of infected material was $2 \mathrm{~g}$ 
amount of viroid was detected in the fractions consisting of resuspended pellets from $\mathrm{LiCl}$ treatment ; on the contrary viroid RNA was present in the supernatant from $\mathrm{LiCl}$ treatment as well in borate as in glycine buffer. Highest sensitivity of the test was obtained after precipitation by $2 \mathrm{M} \mathrm{LiCl}$ : in this case $12 \mathrm{mg}$ infected material are sufficient to detect viroid RNA. With $1 \mathrm{M} \mathrm{LiCl}$ or in the absence of $\mathrm{LiCl}$ treatment, $100 \mathrm{mg}$ infected material are required to detect the viroid RNA.

In order to reduce the duration of the test, we used a dialysis of $4 \mathrm{~h}$ instead of one night. Under these conditions the test can be readily completed within 2 days. Total elimination of the dialysis did not appear possible for 2 reasons, necessity of lowering the salt content and

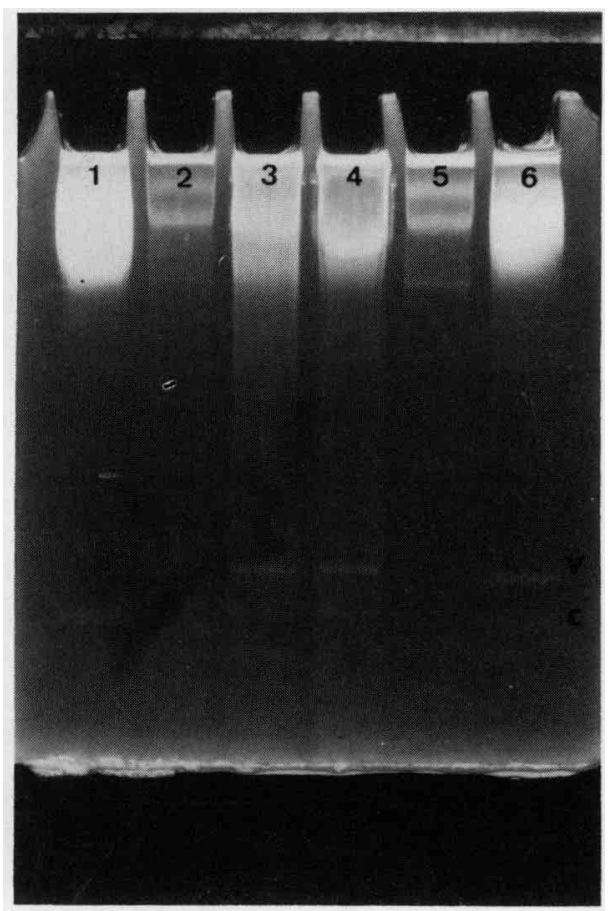

Figure 1

Effect of extraction buffer and LiCl treatment on the detection of CChMV. Nucleic acid suspension applied to each track corresponds to $100 \mathrm{mg}$ infected leaves.

Extraction in glycine buffer :

supernatant from $2 \mathrm{M} \mathrm{LiCl}$ treatment $\quad: 3$

pellet from $2 \mathrm{M} \mathrm{LiCl}$ treatment

control from healthy plant

(supernatant $2 \mathrm{M} \mathrm{LiCl}$ )

control from CSV infected plant

(supernatant $2 \mathrm{M} \mathrm{LiCl}$ )

Extraction in borate buffer :

supernatant from $2 \mathrm{M} \mathrm{LiCl}$ treatment

pellet from $2 \mathrm{M} \mathrm{LiCl}$ treatment

$v$ : viroid RNA; $c$ : cell RNA.

Effet du tampon d'extraction et du traitement par $\mathrm{LiCl}$ sur la détection du CChMV. Les suspensions d'acides nucléiques déposées sur chaque piste correspondent à $100 \mathrm{mg}$ de matériel infecté. Extraction dans le tampon glycine :

surnageant du traitement par LiC $12 \mathrm{M}$

culot du traitement par $\mathrm{LiCl} 2 \mathrm{M}$

extrait témoin de plante saine

(surnageant $\mathrm{LiCl} 2 \mathrm{M}$ )

extrait témoin de plante infectée par le CSV

(surnageant $\mathrm{LiCl} 2 \mathrm{M}$ )

Extraction dans le tampon borate :

surnageant du traitement par $\mathrm{LiCl} 2 \mathrm{M}$

culot du traitement par $\mathrm{LiCl} 2 \mathrm{M}$

$v=R N A$ viroïdal; $c=R N A$ cellulaire. elimination of pigments present in the extracts. Omission of the dialysis results in a poor resolution of the gels.

\section{Detection of CChMV in infected plants. Distribution of the viroid in the plant}

The slab gel technique was used to test the material extracted from different parts of the infected plant in order to assess the viroid content and determine the best material for reliable routine indexing. RNAs were extracted from apex, young and old leaves (veins and lamina), barks and roots. Results of these investigations are illustrated on figure 2 : the viroid was detected in each extract. There seems to exist a certain correlation between viroid RNA and cell RNA concentration in the infected tissues. In another experiment viroid concentrations in different tissues were estimated by applying to the gel several dilutions of the nucleic acid solutions and expressed in terms of the minimum amount of plant material required to detect the viroid. Viroid RNA was detected in samples consisting of $12 \mathrm{mg}$ young leaves or roots. In the case of old leaves, more than $50 \mathrm{mg}$ were needed to ensure the detection of viroid RNA. Nevertheless this quantitative approach should be considered as a simple estimation since these differences could reflect the effect of the nature or the age of the tissue

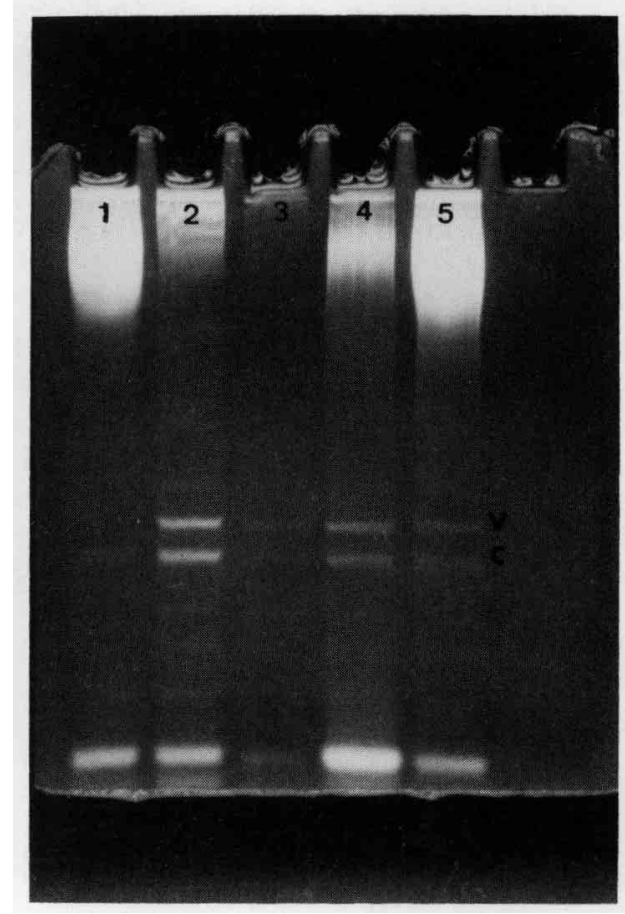

Figure 2

Distribution of the viroid in the infected plant : slab gel electrophoresis of samples from different parts of an infected plant: tip (2), bark (3), young leaves (4), roots (5); control from healthy plant (1). Nucleic acid suspension applied to each track corresponds to $100 \mathrm{mg}$ infected material.

$v$ : viroid RNA; c : cell RNA.

Distribution du viroïde dans la plante infectée ; électrophorèse en plaques d'échantillons issus de différentes parties d'une plante infectée: extrémité apicale (2), écorce (3), jeunes feuilles (4), racines (5); extrait témoin de plante saine (1). Les suspensions d'acides nucléiques déposées sur chaque piste correspondent à $100 \mathrm{mg}$ de matériel infecté.

$v$ : RNA viroidal ; $c: R N A$ cellulaire. 
on the RNA extraction. However our estimations of the distribution of the viroid in the infected tissues are in agreement with the data reported by MORRIS \& WRIGHT (1976) for PSTV.

As we reported previously, production of viroid free material from infected plants is possible by meristem tip culture (BACHELIER et al.,1976) but the percentage of viroid free plants is very low. Therefore, it is crucial to test the plantlets from meristem tip culture very early in order to avoid propagation of infected plants. Slab gel electrophoresis was applied to such plantlets and appeared very suitable to detect infection in this type of material.

\section{Sensitivity of the electrophoretic assay}

Chrysanthemum stunt and chlorotic mottle have been purified (MONSION et al., in preparation). The sensitivity of the electrophoretic assay was assessed with purified viroid preparations: less than $10 \mathrm{ng}$ viroid RNA can be easily detected. This high sensitivity results from a type of "stain " specific of double stranded structures and furthermore, slab gels are perfectly adapted to the type of photographic reading required by this stain. Compared to previous electrophoretic methods, the slab gel technique allows viroid detection from $50 \mathrm{mg}$ infected leaves when stained with toluidine blue 0 and $12 \mathrm{mg}$ with ethidium bromide ; cylindrical gels stained with toluidine blue need $500 \mathrm{mg}$ infected leaves for viroid detection and are very difficult to handle in a routine indexing. These results are identical to those already reported with CSV (MONSION et al., 1980).

\section{Respective reliability of the bioassay and the electrophore- tic assay}

The experiment was carried out with 20 plants of the $\mathrm{cv}$. "Deep Ridge" artificially infected by chip budding with CChMV. The plants were maintained in a conditioned room during 45 days. The first samples were checked by the electrophoretic assay 5 days after inoculation and other samples were taken and checked every 2 or 3 days. Table 2 summarizes the results of this experiment. The first mottle

TABLE 2

Comparative detection of CChMV by bioassay and electrophoretic assay

Comparaison de la détection du CChMV par les techniques d'indexage biologique et électrophorétique

\begin{tabular}{cccc}
\hline \hline \multicolumn{2}{c}{ Bioassay } & \multicolumn{2}{c}{ Electrophoretic assay } \\
\hline $\begin{array}{c}\text { First } \\
\text { symptoms } \\
\text { (in days after } \\
\text { inoculation) }\end{array}$ & $\begin{array}{c}\text { Plants with } \\
\text { sympt. }\left(^{*}\right) \\
\text { Inoculated } \\
\text { plants }\end{array}$ & $\begin{array}{c}\text { First viroid } \\
\text { detection } \\
\text { (in days } \\
\text { after inocul.) }\end{array}$ & $\begin{array}{c}\text { Infected } \\
\text { plants }\left(^{*}\right) \\
\text { Inoculated } \\
\text { plants }\end{array}$ \\
\hline 20 & $8 / 19$ & 14 & $19 / 19$ \\
\hline
\end{tabular}

(*) Results recorded at the end of the experiment, 45 days after inoculation. symptoms could be observed 20 days after inoculation. In the case of CSV, infected plants developed symptoms rapidly after 3-4 weeks incubation; more than 90 p. 100 inoculated plants react within 6-8 weeks. By contrast, CChMV symptoms develop more slowly; at the end of the experiment, 45 days after inoculation, only $8 / 19$ plants exhibit typical symptoms and these results show that one cannot rely on the biological assay for the detection of CChMV. The first case of infection was noticed by the electrophoretic assay 14 days after inoculation, i.e 6 days earlier than the first symptoms. All the plants were investigated by this technique at the end of the experiment : all appeared to be infected, not only the 8 plants with visible symptoms but also the 11 plants without any symptom. This results demonstrate that the electrophoretic assay is much more sensitive and reliable than the bioassay.

\section{CONCLUSIONS}

Our results demonstrate that the electrophoretic assay already used for the detection of PSTV and CSV (SCHU. MANN et al., 1978 ; MONSION et al., 1980) is perfectly applicable to the detection of CChMV. During the rapid purification procedure prior to the electrophoresis, the CChMV RNA does not behave differently from the other purified viroids. In particular, it does not precipitate in the presence of $2 \mathrm{M} \mathrm{LiCl}$.

The electrophoretic assay cannot differenciate CSV and CChMV : both viroids show the same migration in $5 \mathrm{p} .100$ polyacrylamide gels. But the possibility of application of a versatile technique capable to detect at the same time the two viroids of Chrysanthemum represents and advantage in a large scale indexing.

When we consider the erratic response to infection of susceptible cultivars, the electrophoretic assay is much more reliable than the bioassay. It does not require that the plants be grown at $30^{\circ} \mathrm{C}$ prior to the test. Viroid is detected as well in plants with symptoms as in symptomless infected plants. There seems to be no difference between the biological properties of the isolates of CChMV tested in our work. Nevertheless, it seems reasonable to assume, as already reported for PSTV by SCHUMANN et al. (1978) that, in contrast to the bioassay, the electrophoretic assay is not strain discriminating and can detect the mild strains as well as the severe ones.

Besides its interest as a detection technique, the electrophoretic assay can be also very useful for the control of the presence of viroid in different plant extracts and specially in the fractions obtained at different steps of the purification procedure. Such controls assessing the presence of viroid in a given fraction can be carried out by mechanical inoculation but the rate of CChMV transmission is usually very low and symptoms only develop after a long incubation period. By the electrophoretic assay, control of the presence of viroid is obtained within some hours and, when carried out with several dilutions of the preparations, this test can also be used for quantitative purposes.

By its facility, rapidity and high sensitivity, the slab gel electrophoretic assay appears not only interesting for its application to routine viroid indexing but also very appropriate to the search for new viroids. 


\section{REFERENCES BIBLIOGRAPHIQUES}

Bachelier J. C., Monsion Marie, Dunez J., 1976. Possibilities of improving detection of chrysanthemum stunt and obtention of viroid-free plants by meristem-tip culture. Acta Hortic., 59, 63-69.

Dimock A. W., Geissinger C., 1969. A newly recognized disease of chrysanthemums caused by a graft-transmissible agent. Phytopathology, 59, 1024.

Monsion Marie, Macquaire G., Bachelier J. C., Faydi Christine, Dunez J., 1980. Detection of chrysanthemum stunt and chlorotic mottle viroids by slab gel electrophoresis. Acta Hortic., 110.

Morris J., Smith E. M., 1977. Potato spindle tuber disease : procedures for the detection of viroid RNA and certification of disease-free potato tubers. Phytopathology, 67, 145-150.
Morris J., Wright N. S., 1975. Detection on polyacrylamide gel of a diagnostic nucleic acid from tissue infected with potato spindle tuber viroid. Ann. Potato J., 52, 57-63.

Paludan N., 1974. Chrysanthemum chlorotic mottle and stunt Infection trials thermotherapy and meristem-tip culture. Tidsskrift. Planteavl., 78, 85-90.

Romaine C. P., Horst R. K., 1975. Suggested evidence for viroid etiology of chrysanthemum chlorotic mottle disease. Virology, 64, 86-95.

Schumann G. L., Thurston H. D., Horst R. K., Kawamoto S. O., Nemoto G. I., 1978. Comparison of tomato bioassay and slab gel electrophoresis for detection of potato spindle tuber viroid in potato. Phytopathology, 68, 1256-1259. 